\title{
PENILAIAN KINERJA TELLER DALAM UPAYA MENINGKATKAN PELAYANAN NASABAH PT. BPR OPHIRPASAMAN BARAT
}

\author{
Merina Wati, Elva Dona \\ Akademi Keuangan dan Perbankan "Pembangunan" Padang \\ Merinawati14@gmail.com
}

\begin{abstract}
Banking is one business entity that seeks in the field of financial services. PT. BPR Ophir Pasaman Barat is a financial institution that raises savings and distributes funds to the public. The spearhead of the financial industry is service, at PT. BPR Ophir Pasaman Barat main service is at the teller. The formulation of the problem taken is how the performance of teller PT. BPR Ophir Pasaman Barat. The purpose of this study to determine the performance of tellers in improving customer service PT. BPR Ophir Pasaman Barat.Reseorch methods descriptive qualitative in which judgement sampling, in data collection to conduct research on customers of PT. BPR Ophir Pasaman Barat from the twenty-fifth to the twenty-seventh of January 2018. The researcher interviewed thirty customers at that time was the customer who had transacted with the teller. The ratings assessed by the customer are five indicators or aspects (Tangible, responsiveness, assurance, reliability, and Emphaty). Conclusions drawn from customer ratings about teller service at PT. BPR Ophir Pasaman Barat is good.
\end{abstract}

Keywords: Performance, financial instution

\section{PENDAHULUAN}

Perbankan merupakan salah satu badan usaha yang berusaha dalam bidang pelayanan jasa keuangan.Perbankan atau biasa disebut dengan bank menyediakan jasa keuangan bagi seluruh lapisan masyarakat. Fungsi bank merupakan perantara di antara masyarakat yang membutuhkan dana dengan masyarakat yang kelebihan dana, di samping menyediakan jasa-jasa perbankan lainnya Kasmir (2002). Bank memiliki peran sebagai lembaga perantara antara unit-unit ekonomi yang mengalami kelebihan dana dengan unit-unit yang mengalami kekurangan dana. Melalui bank, kelebihan tersebut dapat disalurkan kepada pihak-pihak yang memerlukan sehingga memberikan manfaat kepada kedua belah pihak. Kualitas bank sebagai lembaga perantara ditentukan oleh kemampuan manajemen untuk melaksanakan perannya Sudarsono (2004).

Dunia perbankan harus mampu mewujudkan kepuasan penilaian kinerja terhadap pelayanan nasabahnya, sebab jika nasabah tidak merasa puas terhadap pelayanannya maka nasabah akan meninggalkan perusahaan dan menjadi nasabah pesaing. Hal ini akan berakibat pada menurunnya laba dan bahkan bisa menyebabkan kerugian. Membangun kepuasan pelayanan nasabah merupakan inti dari pencapaian profitabilitas jangka panjang. Pelayanan dan profit ibarat dua sisi mata uang yang tidak dapat dipisahkan. Pelayanan yang baik akan berpengaruh 
terhadap profit. Artinya, pelayanan yang baik akan menciptakan suasana kesinambungan (sustainable). Jika sebuah bank menginginkan profit yang besar, maka bank harus mendapatkan nasabah yang prospeknya bagus. Tentunya nasabah membutuhkan tingkat pelayanan yang lebih komplit, karena nasabah yang prospeknya baik akan menyimpan uangnya di bank dan meminjam atau menginvestasikan uangnya.

Menurut Kotler dalam Zuhri (2009) mengemukakan kualitas pelayanan dari dua sisi, yaitu dari produsen dan konsumen dimana kualitas dari kacamata produsen adalah suatu strategi dasar bisnis yang menghasilkan barang dan jasa yang memenuhi kebutuhan dan kepuasan nasabah internal dan eksternal. Sedangkan defenisi kualitas dari nasabah adalah kualitas merupakan seluruh ciri atau sifat dari suatu produk atau pelayanan yang berpengaruh pada kemampuan untuk memuaskan kebutuhan yang dinyatakan. Menurut Moenir (2005) menjelaskan bahwa pelayanan ialah sebuah proses dari pemenuhan kebutuhan melalui aktivitas orang lain secara langsung. Pelayanan tercermin dari kinerja para pegawai dalam ini pegawai bank PT. BPR Ophir Pasaman Barat.

Penilaian kinerja merupakan suatu proses organisasi dalam menilai unjuk kerja pegawainya. Tujuan dilakukan penilaian kinerja secara umum adalah untuk memberikan feedback kepada pegawai dalam upaya memperbaiki tampilan kerjannya. Dengan demikian faktor-faktor yang perlu diperhatikan dalam menghadapi persaingan ini adalah dengan cara meningkatkan penilaian pelayanan kinerja teller yang diberikan kepada para nasabah.

Dalam usaha mengatasi persaingan perbankan dan PT. BPR Ophir Pasaman Barat yang semakin ketat maka perbankan berupaya meningkatkan penilaian kinerja pegawainya terutama teller karena posisi ini yang berhubungan secara langsung dengan nasabah.Suatu bank harus melakukan kegiatan pelayanan yang dapat membuat nasabahnya merasa puas khususnya dari segi pelayanan teller yang cepat dan teliti sehingga memberikan kenyamanan bagi nasabah yang melakukan transaksi.Untuk mempertahankan dan meningkatkan nasabahnya maka teller perlu menjaga citra positif di mata nasabahnya.Teller merupakan penunjang utama dalam meningkatkan citra perbankan. Menurut Kasmir (2008) tellerberfungsi sebagai orang yang menerima semua setoran uang (tunai maupun non tunai) dari semua pihak. Selain kegiatan tellerdalam menangani keluar masuknya uang setoran, tellerjuga bertanggung jawab pada pemberian pelayanan yang baik, cepat dan tepat kepada nasabah. Teller atau yang biasa disebut juga dengan kasir, merupakan bagian yang berkaitan langsung dengan masalah keuangan, pada setiap hari kasir harus melakukan pembukuan dan penutupan kas.

Bank Perkreditan Rakyat melayani masyarakat sampai kelapisan paling bawah, begitu juga dengan wilayah pasaman barat yang salah satunya BPR yang ada adalah PT. BPR Ophir Pasaman Barat.

PT. BPR Ophir Pasaman Barat merupakan lembaga keuangan yang menghimpun tabungan dan menyalurkan dana kepada masyarakat. Produk yang ditawarkan oleh PT. BPR Ophir pada masyarakat di pasaman barat yaitu Tabungan Plasma, Tabungan Ophir Plasma, dan Tabungan Pelajar Aktif.

Fenomena umum yang sering terjadi pada PT. BPR Ophir Pasaman Barat adalah nasabah harus antri dan menunggu sebelum mendapatkan pelayanan dari 
Teller. Dalam upaya mendapatkan pelayanan dari Teller, nasabah sering menilai kualitas pelayanan Teller terhadap cara melayani nasabahnya. Berdasarkan lamanya waktu menunggu atau kecepatan Teller dalam memberikan pelayanan kepada para nasabahnya.Nasabah dapat memberi penilaian dari pelayanan Teller selama mereka melakukan transaksi.

Teller yang ada pada PT. BPR Ophir Pasaman Barat berjumlah satu orang, pelayanan terutama pada tanggal 6 sampai dengan tanggal 10 pada nasabah sangat tinggi, karena pada tanggal tersebut nasabah melakukan pengambilan gaji melalui buku tabungan mereka. Pada umumnya setiap nasabah mengharapkan segera mendapatkan pelayanan dari teller tanpa harus menunggu lama.Pada waktu setelah tanggal sepuluhan ini relatif tidak ada penumpukan nasabah sehingga dapat terlayani oleh teller.Secara keseluruhan kinerja teller dapat diketahui dari penilaian nasabah terhadap pelayanan yang mereka terima.Kinerja ini dapat dilihat dari aspek Tangible, Responsivennes, Assurance, Reliability dan Emphaty.

Melihat pentingnya penilaian kinerja teller penulis tertarik untuk mengadakan penelitian dengan berjudul " Penilaian Kinerja Teller Dalam Upaya Meningkatkan Pelayanan Nasabah pada PT. BPR Ophir Pasaman Barat “.

\section{METODE PENELITIAN}

Penelitian ini menggunakan metode kualitatif yang sifatnya deskriptif dimana sampel diambil berdasarkan judgement sampling.Dalam pengumpulan data dan bahan untuk melakukan penelitian ini dilakukan dengan wawancara terhadap nasabah, berdasarkan judgement sampling yaitu nasabah PT. BPR Ophir Pasaman Barat dari tanggal dua puluh lima sampai dengan tanggal dua puluh tujuh Januari 2018. Peneliti melakukan wawancara terhadap tiga puluh orang nasabah dimana nasabah pada waktu tersebut adalah nasabah yang sudah bertransaksi dengan teller. Berdasarkan Uma Sekaran (2000) jumlah sampel minimum adalah sebanyak tiga puluh sampel.

\section{HASIL PENELITIAN \\ Pengertian Bank}

Bank adalah suatu badan usaha yang paling penting dalam memberikan pelayanan keuangan demi menunjang perekonomian. Menurut Yogi Prasanjaya ( 2013 ) Bank adalah bagian dari sistem keuangan, yang memainkan peranan dalam berkontribusi terhadap pembangunan ekonomi suatu negara. Dari pengertian sebelumnya maka dapat disimpulkan pengertian bank adalah suatu badan keuangan yang dibawah naungan Undang-Undang suatu Negara yang berkekuatan hukum, sehingga bank diwajibkan mentaati dan mengikuti prosedur yang telah ditetapkan.

Bank juga merupakan sebuah lembaga intermediasi keuangan yang umumnya didirikan dengan kewenangan untuk menerima simpanan uang, meminjam uang, dan menerbitkan promes atau yang dikenal sebagai bank note.

Sedangkan pengertian bank menurut Undang-Undang Negara Republik Indonesia Nomor 10 Tahun 1998 Tanggal 10 November 1998 tentang perbankan, yang dimaksud dengan bank adalah badan usaha yang menghimpun dana dari masyarakat dalam bentuk simpanan dan menyalurkan kepada masyarakat dalam 
bentuk kredit dan bentuk-bentuk lainnya dalam rangka meningkatkan taraf hidup rakyat banyak.

\section{Jenis Bank}

Menurut Kusnandar (2013) jenisnya bank dibedakan menjadi 2 terdiri dari Bank umum, dan Bank Perkreditan Rakyat (BPR), mempunyai fungsi yang sama yaitu sebagai penghimpun dan penyalur dana masyarakat.

Dalam hal ini menandakan bahwa bank sangatlah penting dalam pembangunan nasional karena fungsi bank dalam Pasal 1 angka 2 UU perbankan mendefinisikan fungsi bank adalah badan usaha yang menghimpun dana dari masyarakat dalam bentuk simpanan dan menyalurkannya kepada masyarakat dalam bentuk kredit dan atau bentuk-bentuk lainnya dalam rangka meningkatkan taraf hidup rakyat banyak.

\section{Penilaian Kinerja}

Penilaian kinerja keuangan merupakan salah satu faktor penting bagi perusahaan, tidak terkecuali perusahaan perbankan.Penilaian kinerja atas kepuasan dan ketidakpuasan secara umum merupakan hasil dari perbandingan antara harapan nasabah atas produk yang dibeli dengan kinerja aktual produk tersebut.

Menurut William Bearden (2006) kepuasan nasabah dapat diukur dengan menilai bagaimana cara teller dalam memberikan pelayanan nasabah terhadap produk yang digunakan. Kinerja diukur berdasarkan indikator kinerja Tangible, Responsivennes, Assurance, Reliability dan Emphaty.

\section{Pengertian Teller}

Telleradalah petugas bank yang bertanggung jawab terhadap lalu lintas uang tunai .Telleratau yang bisa disebut juga dengan kasir, merupakan bagian yang berkaitan langsung dengan masalah keuangan.Pada setiap hari, kasir harus melakukan pembukaan dan penutupan kas.Serta bertugas membuat, merencanakan kebutuhan kas harian, mencatat semua transaksi kas dan juga merekapnya dalam catatan uang keluar dan masuk.Staf khusus pada kasir harus terpisah dengan bagian pembukuan.Pada tahap awal staf kasir dapat berfungsi ganda yaitu sebagai fungsi pelayanan nasabah. Namun, pada perkembangannya, dapat dibentuk staf khusus yang akan menangani masalah jasa pelayanan nasabah. Bagian ini juga merupakan bagian terdepan dari pelayanan PT. BPR Ophir Pasaman Barat.Produk yang digunakan PT. BPR Ophir Pasaman Barat adalah produk Tabungan Plasma, Tabungan Ophir Plasama dan Tabungan Pelajar Aktif.

\section{Tujuan dan Manfaat Penilaian Kinerja Teller}

\section{a. Tujuan Penilaian Kinerja Teller}

Tujuan diadakan penilaian kinerja bagi Teller dapat kita ketahui dibagi menjadi dua, yaitu: 1) Tujuan evaluasiSeorang manajer menilai kinerja dari masa lalu seorang Teller dengan menggunakan deskriptif untuk menilai kinerja dengan data tersebut berguna dalam keputusan-keputusan promosi, demosi, terminasi dan kompensasi. 2) Tujuan pengembanganSeorang manajer mencoba untuk meningkatkan kinerja seorang Teller dimasa yang akan datang.

b. Manfaat Penilaian Kinerja TellerPada umumnya bagi nasabah dapat menilai bagaimana kinerja teller dalam melayani nasabah tersebut. Bagi teller, penilaian tersebut berperan sebagai umpan balik tentang berbagai hal seperti kemampuan, 
kelebihan, kekurangan, dan potensi yang pada gilirannya bermanfaat untuk menentukan tujuan, jalur, rencana dan pengembangan karir.

Manfaat bagi perusahaan, hasil penilaian nasabahsangat penting artinya untukmengambil keputusan tentang berbagai hal, seperti identifikasi kebutuhan program pendidikan dan pelatihan, rekruitment, seleksi, program pengenalan, penempatan, promosi, sistem imbalan dan berbagai aspek lainnya.

\section{PEMBAHASAN}

Berdasarkan jumlah keseluruhan penilaian kinerja teller ( lampiran tabel 1 dan lampiran tabel 2 ) yang didapat dari penilaian nasabah PT. BPR Ophir Pasaman Barat melalui indikator/aspek Tangible, Responsivennes, Assurance, Reliability, dan Emphaty sebagai berikut :

Aspek Tangible (Bukti Fisik) yaitu penampilan fisik, peralatan dan media komunikasi terhadap kepuasan nasabah.Tangible berpengaruh terhadap kepuasan nasabah. Bukti fisik kebersihan dan kerapian kantor dengan cara memperhatikan setiap sudut ruangan apakah masih kotor atau tidak, oleh sebab itu, Tangible (bentuk fisik) haruslah baik untuk memberikan kenyamanan dan kepuasan kepada nasabah. Nilai Tangible tercemin dari kebersihan teller, penataan peralatan operasional, kelengkapan dan kesiapan teller serta kecepatan teller dalam menyelesaikan transaksi, yang terangkum dalam butir-butir pertanyaan yang ada pada kuesioner.Berikut hasil penilaian kinerja teller berdasar aspek tengible ini pada teller PT. BPR Ophir Pasaman Barat.

\section{Grafik 1}

Tanggapan nasabah terhadap penilaian bukti fisik (tangible)

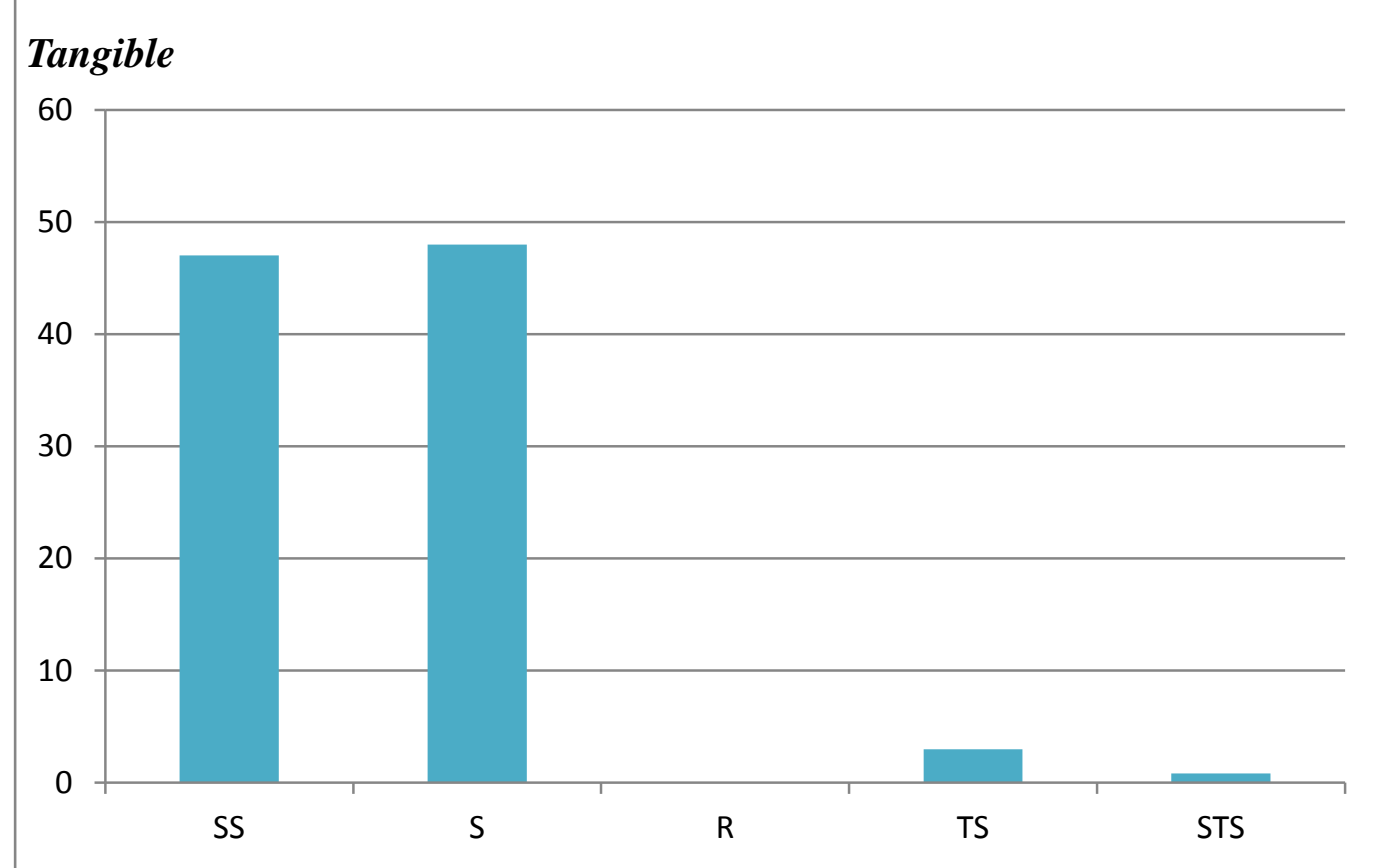

Dilihat dari Grafik 1 bukti kepuasan nasabah terhadap kinerja teller dalam bukti fisik (Tangible) diperoleh point Sangat Setuju sebesar 47,5\% dari 4 butir pertanyaan, yang menyatakan Setuju sebesar 48,33\% dari pertanyaan 1-4, 
sedangkan yang Ragu 0\%, Tidak Setuju 3,33\%, dan sebesar 0,83\% menyatakan Sangat Tidak Setuju. Secara keseluruhan tanggapan nasabah PT. BPR Ophir Pasaman Barat terhadap kinerja teller dari bukti fisik (tangible) baik, dalam hal ini nasabah merasa puas.

Aspek Responsiveness (Ketanggapan) yaitu kemauan untuk membantu pelanggan dan memberikan jasa dengan cepat atau ketanggapan terhadap kepuasan nasabah. Dengan cara lebih menjalin komunikasi lagi kepada nasabah, tidak pilih-pilih nasabah, dan menganggap nasabah itu adalah asset yang berharga bagi perusahaan. Nilai responsiveness tercermin dari teller memberikan informasi yang yang jelas, teller cepat tanggap dalam menyelesaikan masalah yang timbul serta kesopanan dan keramahan teller.Berikut hasil penilaian kinerja teller berdasar aspek Responsivennes terhadap teller PT. BPR Ophir Pasaman Barat.

\section{Grafik 2}

Tanggapan nasabah terhadap penilaian bukti ketanggapan (Responsiveness)

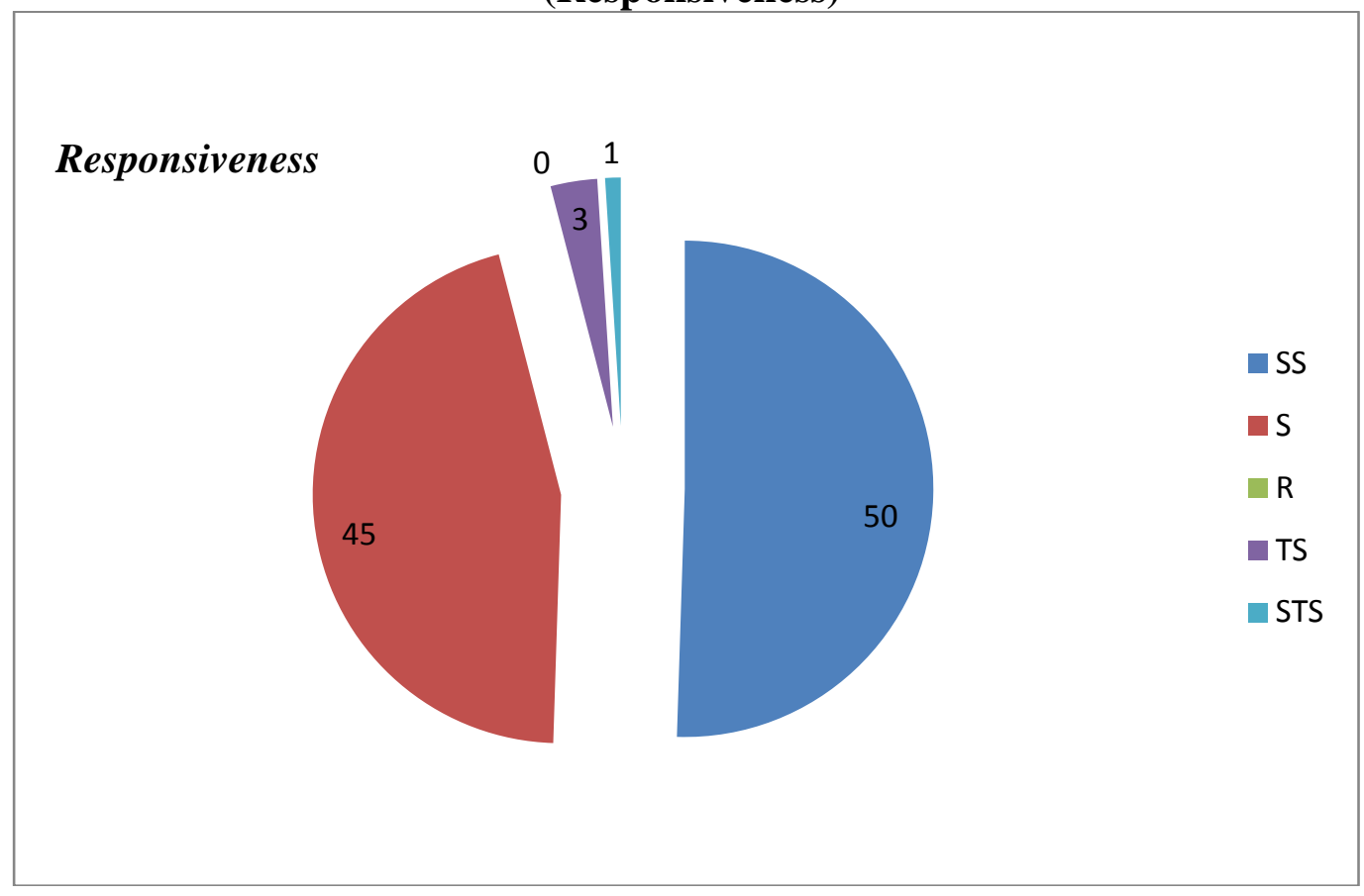

Pada Grafik 2 bukti kepuasan nasabah terhadap kinerja teller dalam bukti Ketanggapan (Responsiveness) diperoleh point Sangat Setuju sebesar 50\% dari 3 butir pertanyaan, yang menyatakan Setuju sebesar $45,55 \%$ dari 3 pertanyaan sedangkan Ragu sebesar 0\%, Tidak Setuju 3,33\%, dan sebesar 1,11\% menjawab Sangat Tidak Setuju. Secara keseluruhan tanggapan nasabah PT. BPR Ophir Pasaman Barat terhadap kinerja teller dalam bukti ketanggapan (Responsiveness) baik.Dari hasil penelitian, bahwa bentuk ketanggapan pelayanan masih baik.Jadi, bentuk ketanggapan dari dimensi kualitas pelayanan lebih ditingkatkan lagi agar dapat memberikan kepuasan nasabah atas layanan yang di dapatkannya.

Aspek Assurance (Jaminan) terhadap kepuasan nasabah seorang tellerharus mampu memberikan solusi terhadap permasalahan yang dihadapi nasabah sehingga nasabah merasa puas dengan pelayanan yang diberikan oleh 
teller, membuat nasabah merasa senang.Karena assurance merupakan salah satu faktor penting dalam terciptanya kepuasan suatu nasabah. Nilai assurance tercermin dari pengetahuan, keramahan teller dalam memproses transaksi keuangan, teller mampu memberikan rasa aman, ketepatan teller dalam menghitung uang, serta jadwal buka dan tutup teller dijalankan dengan tepat waktu. Berikut hasil penilaian kinerja teller berdasarkan aspek Assurance ini pada teller PT. BPR Ophir Pasaman Barat.

\section{Grafik 3}

Tanggapan nasabah terhadap penilaian bukti jaminan

(Assurance)

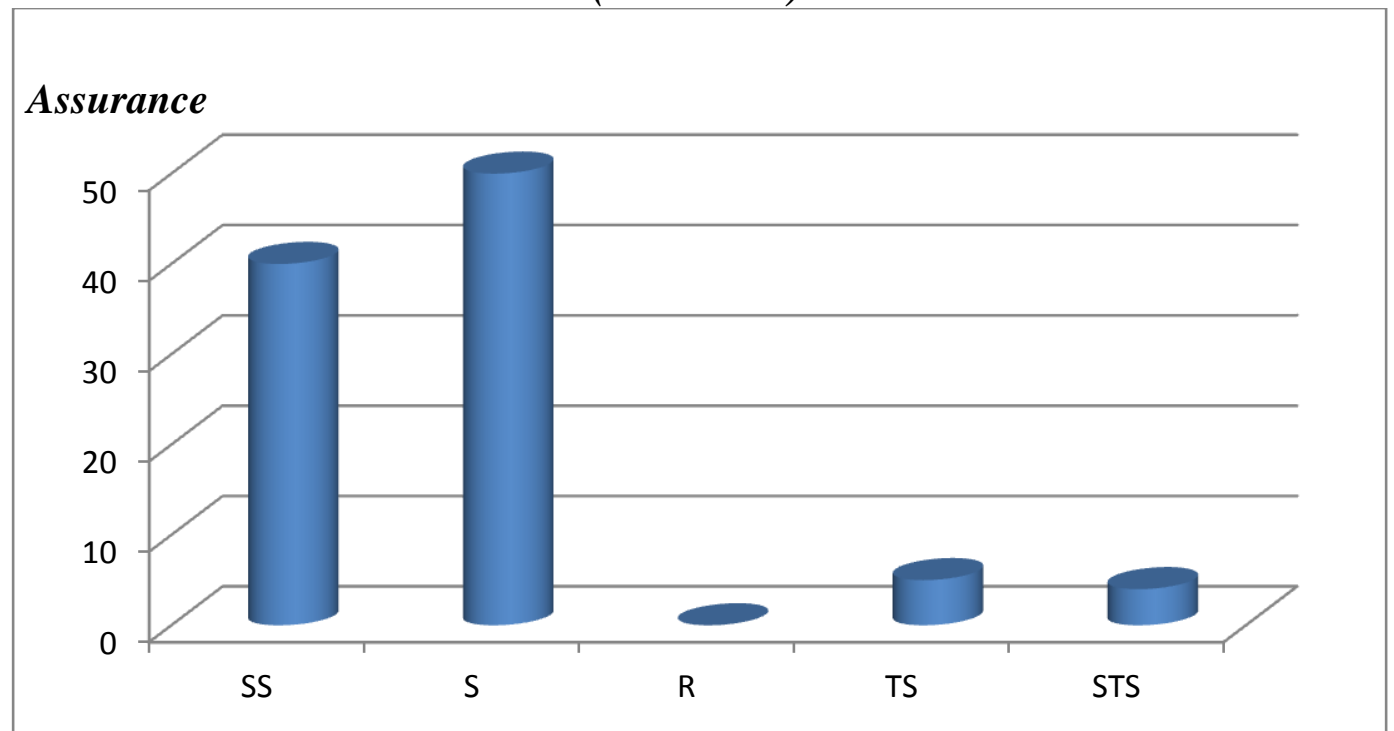

Pada Grafik 3 bukti kepuasan nasabah terhadap kinerja teller dalam bukti Jaminan (Assurance) diperoleh point Sangat Setuju sebesar 40\% dari 4 butir pertanyaan, sedangkan yang Setuju $50 \%$ dari 4 pertanyaan, Ragu 0\%, yang menyatakan Tidak Setuju 5,83\%, dan sebesar 4,16\% menyatakan Sangat Tidak Setuju. Secara keseluruhan tanggapan nasabah PT. BPR Ophir Pasaman Barat terhadap kinerja teller dalam bukti jaminan (Assurance) baik.

Aspek Reliability (Kehandalan) yaitu kemampuan untuk melaksanakan jasa yang dijanjikan dengan tepat dan terpercaya terhadap kepuasan nasabah. Nilai Reliability tercermin dari teller mendengarkan baik-baik ketika nasabah meminta pelayanan transaksi, teller memperhatikan setiap keluhan nasabah, serta teller memberikan pelayanan yang sama kepada semua nasabah tanpa memandang status. Berikut hasil penilaian kinerja teller berdasar aspek Reliabilility terhadap teller PT. BPR Ophir Pasaman Barat. 


\section{Grafik 4}

\section{Tanggapan nasabah terhadap penilaian bukti kehandalan (Reliability)}

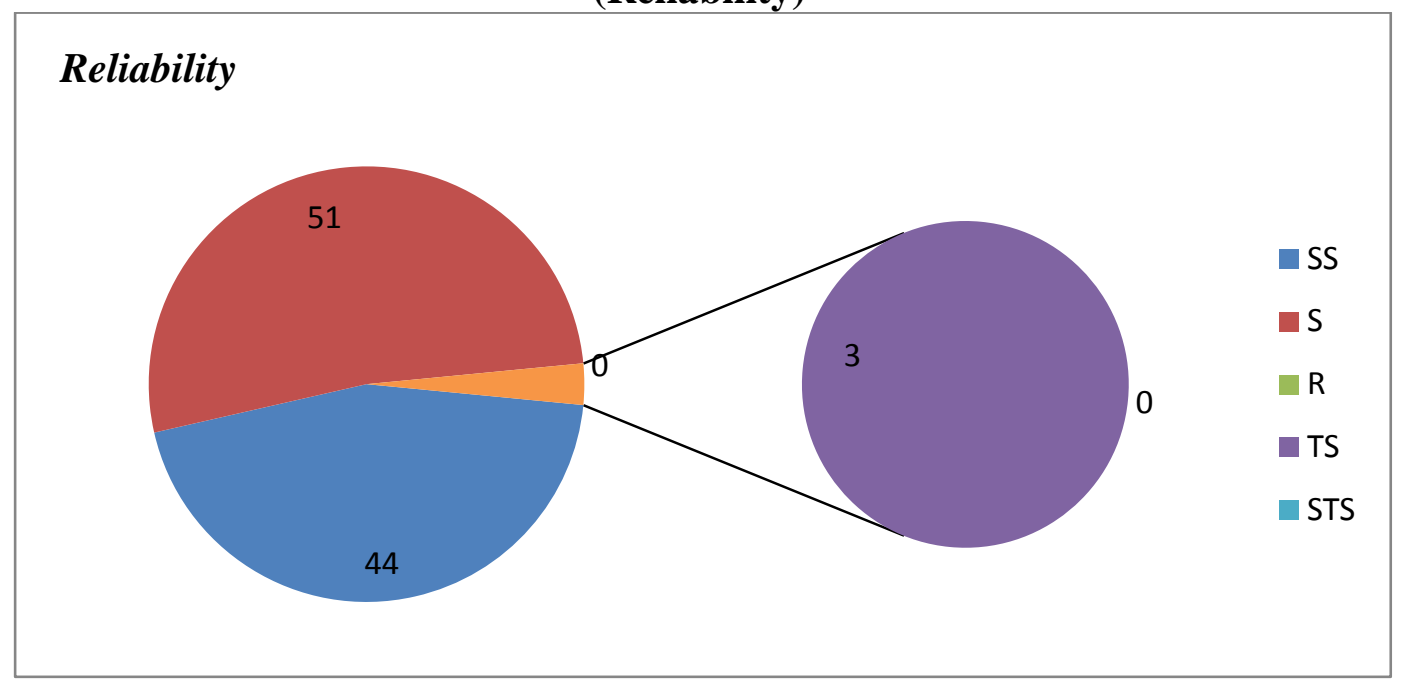

Dari Grafik 4 bukti kepuasan nasabah terhadap kinerja teller dalam bukti Kehandalan (Reliability) diperoleh point Sangat Setuju 44,94\% dari 3 butir pertanyaan, yang menyatakan Setuju $51,68 \%$ dari 3 pertanyaan, Ragu 0\%, sedangkan yang Tidak Setuju sebesar $3,37 \%$, dan tidak ada yang menyatakan Sangat Tidak Setuju atau 0\%. Secara keseluruhan kinerja teler PT. BPR Ophir Pasaman Barat dalam bukti kehandalan (Reliability) baik. Jadi, Dari hasil penelitian penulis yang perlu ditingkatkan lagi adalah ketelitian teller dalam setiap melakukan pelayanan dengan cara mengikuti pelatihan keterampilan pegawai yang biasanya diadakan oleh pihak bank. Karena ketelitian termasuk salah satu bagian yang penting dalam menentukan kepuasan nasabah. Karena dengan ketelitian pelayanan teller akan membuat nasabah merasa puas akan hal tersebut.

Aspek Emphaty (Perhatian) yaitu syarat untuk peduli memberikan perhatian pribadi kepada pelanggan terhadap kepuasan nasabah.Nilai Emphaty tercermin dari kebersihan teller, keterampilan teller serta prosedur pelayanan teller tidak berbeli-belit.Berikut hasil penilaian kinerja teller berdasar aspek Emphaty pada teller PT. BPR Ophir Pasaman Barat. 


\section{Grafik 5}

Tanggapan nasabah terhadap penilaian bukti perhatian

(Emphaty)

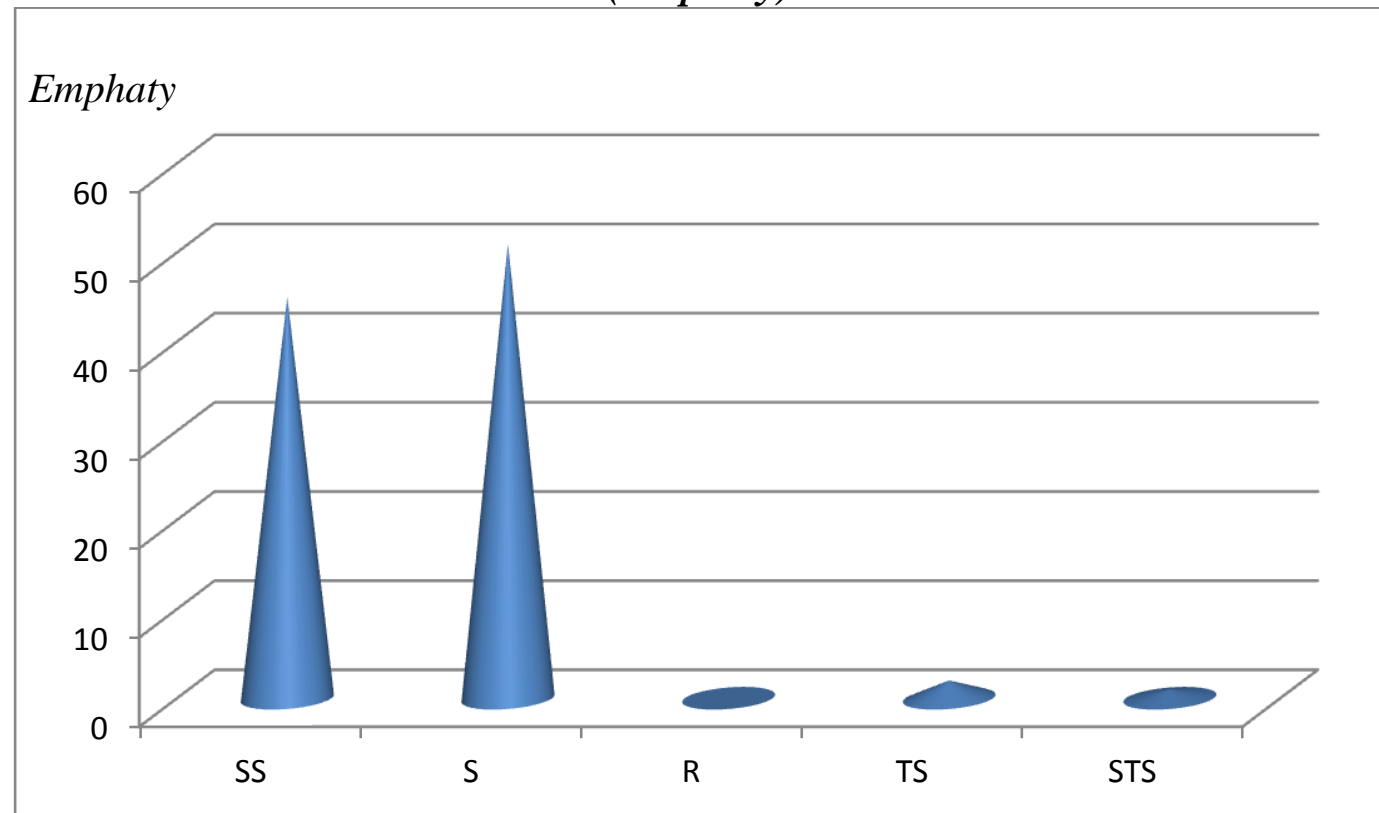

pada Grafik 5 bukti kepuasan nasabah terhadap kinerja teller dalam bukti Perhatian (Emphaty) yang menyatakan Sangat Setuju sebesar 45,55\% dari 3 butir pertanyaan, yang menyatakan Setuju sebesar $51,11 \%$ tidak ada nasabah yang Ragu atau $0 \%$, sedangkan yang menyatakan Tidak Setuju sebesar 2,22\%, dan $1,11 \%$ menyatakan Sangat Tidak Setuju. Secara keseluruhan perhatian (Emphaty) kinerja teller terhadap nasabah PT. BPR Ophir Pasaman Barat baik, terbukti dari hanya $2,22 \%$ nasabah yang merasa terabaikan. Namun, ini tetap menjadi catatan penting oleh PT. BPR Ophir Pasaman Barat karena jenis industri yang dilakukan PT. BPR Ophir Pasaman Barat adalah industri kepercayaan berbasis layanan.Pelayanan prima membuat nasabah loyal. Dari hasil penelitian bahwa yang perlu ditingkatkan lagi adalah kemampuan mengenai kejelasan teller dalam menjelaskan informasi mengenai transaksi-transaksi dengan cara lebih sering mengikuti pelatihan yang diadakan oleh pihak bank atau ada pelatihan khusus. Karena empathy berpengaruh terhadap kepuasan nasabah.Empathy salah satu faktor untuk membuat nasabah merasa puas dengan layanan yang didapatkannya.

\section{SIMPULAN}

Berdasarkan uraian pada bab-bab sebelumnya, maka dapat diambil kesimpulan sebagai berikut :Aspek Tangible bepengaruh terhadap kepuasan nasabah, karena nilai tangible tercermin dari kebersihan teller, penataan peralatan operasional, kelengkapan dan kesiapan teller serta kecepatan teller dalam menyelesaikan transaksi, agar tidak terjadi kemacetan dalam nomor antrian.Aspek Responsivennes ini tercermin dari teller memberikan informasi yang jelas, teller harus cepat tanggap dalam menyelesaikan masalah yang timbul serta kesopanan dan keramahan teller.Aspek Assurance ini berpengaruh tentang memberikan solusi terhadap permasalahan yang dihadapi nasabah sehingga nasabah merasa 
puas dengan pelayanan yang diberikan oleh teller.Aspek Reliability yaitu kehandalan terhadap kepuasan nasabah tentang ketelitian seorang teller setiap melakukan pelayanan.Aspek Emphaty berpengaruh terhadap memberikan perhatian kepada nasabah, jadi setiap aspek memiliki fungsi masing-masing dan bersangkutan maka seorang teller harus menjalani pelayanan berdasarkan aspekaspek diatas.

\section{UCAPAN TERIMAKASIH}

Puji dan syukur kita panjatkan atas kehadiran Allah SWT, atas berkat rahmat dan karunia-Nya yang senantiasa dilimpahkan kepada kiya semua. Sholawat dan salam semoga tercurahkan pada Nabi Muhammad SAW yang telah menyampaikan risalah dan syariat islam kepada seluruh umat manusia. Dan terimakasih kepada dosen Buk Elva Dona, SE.ME selaku dosen pembimbing yang telah bersedia untuk meluangkan waktu untuk membimbing, memeriksa serta memberikan arahan-arahan serta saran dalam penyusunan artikel ini, Kepada keluarga besar AKBP STIE "KBP" PADANG, staf dosen dan karyawan yang telah banyak memberikan ilmu pengetahuan serta bantuan selama ini sehingga penulis bisa menyelesaikan artikel ini. Ayah Isman dan Ibu Nuralis tersayang, yang selalu mendoakan dan memberikan dukungan baik moril maupun materil kepada penulis.

\section{DAFTAR PUSTAKA}

Anita Ambariki (2005). analisis tingkat kepuasan nasabah atas pelayanan teller pada bank permata area jakarta.

Dona, E. (2018). Kepuasan Publik Dilihat Dari Kualitas Pelayanan Dalam Pengurusan Perizinan (Kasus Badan Pelayanan Perizinan Terpadu, Pengadaan Barang Dan Jasa Kab. Dharmasraya). Https://Doi.Org/10.31227/Osf.Io/8cjhg.

Fernandes, Y. D., \& Marlius, D. (2018). Peranan Customer Service Dalam Meningkatkan Pelayanan Kepada Nasabah Pada PT. Bank Pembangunan Daerah Sumatera Barat Cabang Utama Padang. https://doi.org/10.31227/osf.io/wrh3p

Kasmir ( 2002 ). Bank dan Lembaga Keuangan Lainnya, pengertian teller, dan dasar-dasar perbankan edisi Enam. Jakarta: PT Raja Grafindo Persada.

Kotler ( 2009 )Manajemen Pemasaran: Analisis, Perencanaan, Implementasi dan Pengendalian.Jakarta : Salemba 4.

Marlius, D. Putriani, I. (2019). Kepuasan Nasabah PT. Bank Rakyat Indonesia Unit Tapan Cabang Painan Dilihat dari Kualitas Layanan Customer Service. Jurnal Pundi. Volume 3. No. 2. Hal.111-122. https://doi.org/10.31575/jp.v3i2.151

Marlius, D. Ananda, F. (2019). Pengaruh Kualitas Pelayanan Website Akademik Terhadap Minat Kuliah di AKBP Padang. Jurnal Pundi, Vol. 03, No. 03. Hal. 191-204. https://doi.org/10.31575/jp.v3i3.190 
Marlius, D. (2018). Loyalitas Nasabah Bank Nagari Syariah Cabang Bukittinggi Dilihat Dari Kualitas Pelayanan. Jurnal Pundi. Volume 1. No. 3. Hal.1222. https://doi.org/10.31575/jp.v1i3.60

Marlius, D. (2018). Pengaruh Dimensi Kualitas Pelayanan Website Akademik Terhadap Kepuasan Mahasiswa Pada STIE “KBP”. Jurnal Ipteks Terapan. $\begin{array}{lllll}\text { Volume } & 12 . & \text { No. } & 2 . & \text { Hal. }\end{array}$ http://doi.org/10.22216/jit.2018.v12i2.633

Mirawati \& Fernos, J. (2019). Peranan Customer Service Dalam Meningkatkan Pelayanan Terhadap Nasabah Pada Bank Nagari Cabang Siteba Padang. https://doi.org/10.31227/osf.io/cq458

Moenir ( 2005 ).Akuntansi Manajemen: pengertian pelayanan, penilaian kinerja dan Konsep, edisi 3. Jakarta : Salemba Empat.

Mulyadi dan J. Setyawan. 2001. Sistem Perencanaan dan Pengendalian Manajemen: Sistem Pelipatganda Kinerja Perusahaan. edisi 2. Jakarta : Salemba Empat.

Ningsih ( 2009 ). "Tingkat Kepuasan Anggota BMT Sumber Mulia Tuntang". Tugas Akhir. STAIN Salatiga.

Oktivinanto ( 2012 ). "Tingkat Kepuasan Nasabah Bank Syariah Mandiri Cabang Salatiga Diukur Dari Dimensi Kualitas Pelayanan”. Tugas Akhir. STAIN Salatiga.

Prasetyo, W. (2015). Analisis faktor-faktor yang mempengaruhi profitabilitas perbankan. Jesp, 7(1), 46-54.

Putra, A. M., \& Fernos, J. (2019). Pelaksanaan Pelayanan Prima Terhadap Kepercayaan Nasabah Di PT. Bank Perkreditan Rakyat Jorong Kampung Tangah Pariaman. https://doi.org/10.31227/osf.io/c3fy4

Sudarsono ( 2004 ).Kualitas bank sebagai perantaraEdisi Ketujuh. Bandung: CV Alfabeta.

Sugiyono. 2012. Metode Penelitian Kuantitatif, Kualitatif, dan R\&D. Cetakan ke17. Bandung: Alfabeta.

Wulan, A. R. (2010). Penilaian Kinerja Dan Portofolio Pada Pembelajaran Biologi, 1-16.

Yuvendri, R., \& Susanto, R. (2019). Meningkatkan Mutu Pelayanan Dalam Usaha Menghimpun Dana Masyarakat (Tabungan) Pada PT. Bank Perkreditan Rakyat Prima Mulia Anugrah Cabang Padang. https://doi.org/10.31219/osf.io/6prcd

Zuhri (2009) "Pengaruh Kualitas Jasa Pelayanan nasabah dan Diversifikasi Produk terhadap Kepuasan Nasabah di BMT Tumang Kecamatan Ampel Kabupaten Semarang Boyolali”. Skripsi: UMS. 